\title{
Webjornalismo participativo: repensando algumas questões técnicas e teóricas
}

\section{RESUMO}

O advento das tecnologias digitais e da rede mundial de computadores resultou em um novo suporte midiático, que vem trazendo modificações significativas ao campo da comunicação. Um exemplo recente é o jornalismo participativo na Internet, que possibilita a qualquer cidadão transformar-se em produtor de notícias. Neste artigo, procura-se refletir sobre essa prática à luz das teorias, conceitos e ideais do jornalismo tradicional, a fim de identificar mudanças, adaptações ou rupturas entre um e outro modo de produção e circulação.

\section{PALAVRAS-CHAVE}

- internet

- jornalismo

- webjornalismo participativo

\section{ABSTRACT}

The advent of digital technologies and computers' worldwide net resulted in a new mediatic support, which brings significant modifications to the communication area. A recent example of it is the open-source (participant) journalism in the Internet, which allows any citizen to become a news producer. The purpose of this paper is to reflect on this practice in the light of the theories, concepts and ideals of traditional journalism, in order to identify changes, adaptations or ruptures between one and the other.

\section{KEY WORDS}

- internet

- journalism

- open-source (participant) journalism in the Internet.

\section{Virginia Fonseca e Cristiane Lindemann UFRGS}

A s tecnologias digitais de comunicação e informação, definidas por Lemos (2004, p.68) como "a fusão das telecomunicações analógicas com a informática, possibilitando a veiculação, sob um mesmo suporte - o computador -, de diversas formatações de mensagens", têm modificado de maneira expressiva o campo da comunicação. O jornalismo, nesse contexto, não escapa dessas influências, o que torna necessário repensar algumas questões, tanto técnicas quanto teóricas, requeridas por essa nova modalidade de produção e circulação.

Dentre as inovações, há uma gama de produtos e de enfoques que podem embasar uma boa análise de questões contemporâneas. O presente artigo enfoca o jornalismo participativo na Internet: uma prática em que qualquer cidadão pode se tornar repórter, redigindo matérias e/ou enviando fotografias, áudios ou vídeos que são veiculados em sites abrigados na rede mundial de computadores ${ }^{1}$.

O objetivo, neste trabalho, é procurar analisar algumas diferenças entre o webjornalismo participativo e o jornalismo praticado de forma convencional. A modalidade webjornalismo participativo provoca reconfiguração, ruptura e/ou conflito com o jornalismo exercido nas mídias tradicionais? Como se posicionam os jornalistas frente a essas inovações? Pode esta modalidade de produção e circulação de notícias ser classificada de jornalismo? Uma vez assim denominada, a nova prática nos leva a repensar algumas questões, sem, no entanto, ter a pretensão de chegar a um veredicto final. Nossa intenção neste artigo é ampliar e aprofundar o debate a respeito do assunto.

Primeiramente, são apresentados alguns dados históricos, relevantes para a contextualização do tema abordado, que vão do jornalismo tradicional ao jornalismo em rede; depois, discorre-se sobre o jornalismo participativo na Internet, citando-se alguns exemplos; em seguida, para finalizar, discute-se algumas questões relativas ao papel do jornalista, às rotinas de produção e à validação do gatekeeper.

\section{Do jornalismo convencional ao jornalismo em rede}

A necessidade de o ser humano se comunicar, de saber dos fatos e de acompanhar os acontecimentos já se manifestava nas civilizações primitivas, quando as relações face-a-face, a comunicação interpessoal, davam conta de tudo isso. Mas o conhecimento estava limitado àquilo que era repassado oralmente de uma geração para outra - a chamada era da oralidade, quando ainda não existiam as mídias para transmitir informações (Medina, 1978).

A invenção do alfabeto, da escrita e da imprensa, juntamente com as tecnologias de informação desen- 
volvidas a partir da Revolução Industrial, transpôs essa barreira, uma vez que possibilitou a distribuição das informações de modo mais eficiente, assim como o seu registro. "Vencida uma das principais limitações humanas, tempo/espaço, ninguém tem dúvida ao atribuir a vitória aos recursos tecnológicos que veiculam a informação" (Medina, 1978, p.20).

A atividade jornalística, por sua vez, tem suas raízes nas sociedades européias, em um tempo anterior à Revolução Industrial. As primeiras manifestações do gênero, segundo Marques de Melo (1994), aconteceram nos séculos XV e XVI, quando eram publicadas as relações, os avisos e as gazetas, com o intuito de atender às necessidades sociais de informação dos habitantes das cidades, súditos e governantes. É somente a partir da Revolução Francesa, na transição do século XVIII para o século XIX, que o jornalismo se fortalece, assumindo o papel fundamental de mediar e tornar público tudo o que for de relevância para a sociedade.

Marcondes Filho (2000) faz um panorama do desenvolvimento do jornalismo, classificando-o em cinco fases que refletem determinados momentos históricos:

Pré-História do Jornalismo (de 1631 até a Revolução Francesa). Nessa fase, o aparecimento do jornalismo está associado à luta pelos direitos humanos, à destituição da aristocracia, ao fim das monarquias e de todo o sistema absolutista que vinha desde a Idade Média, e à desconstrução do poder da Igreja e da Universidade. O saber acumulado e reservado aos sábios e poderosos passa a circular através dos jornalistas.

Primeiro Jornalismo (de 1789 até 1830). Caracterizada por conteúdo literário e textos de dominação, de manutenção da autoridade e do poder. Tudo deve ser superexposto. O jornal se profissionaliza: surge a redação como um setor específico, o diretor passa a ser uma figura diferente do editor, impõe-se o artigo de fundo e a autonomia redacional. Nesse período, os fins econômicos estão em segundo plano; o jornal tem fins pedagógicos e de formação política.

Segundo Jornalismo (da metade do século XIX até o começo do século XX). As tecnologias possibilitam que o jornal se transforme em grande empresa capitalista. É a imprensa moderna, que funciona de acordo com as exigências do capital. $\mathrm{O}$ valor de troca da notícia passa a ser mais importante que o mero valor de uso, devido à concorrência. Surge a reportagem, e a publicidade passa a ser a principal fonte de manutenção dos periódicos. Imprensa de massa, com caráter libertário e independente.

Terceiro Jornalismo (do início do século XX até a década de 60). Caracterizada pelos monopólios empresariais de comunicação, grandes tiragens, desenvolvimento da indústria publicitária e das relações públicas, que acabam competindo com o jornalismo, o qual passa por um processo de desintegração e enfraquecimento, e vai sendo substituído por proces- sos menos engajados, que não se preocupam tanto em buscar a verdade e não questionam mais a política.

Quarto Jornalismo (dos anos 70 até a contemporaneidade). Fase em que se somam dois processos: a) expansão da indústria da consciência de estratégias de comunicação e persuasão no noticiário; b) substituição do agente humano jornalista pelos sistemas de comunicação eletrônica, que possibilitam novas formas de produção da informação. Caracteriza-se pelas tecnologias digitais e suas possibilidades de interação, multimidialidade, variedade de noticiários e velocidade. Paralelamente, ocorrem crises de credibilidade, de circulação e de profissionalismo.

\section{A idéia de participação é, justamente, descentralizar a emissão, oportunizando que mais vozes tenham vez no espaço público.}

Conforme o autor, essa revolução tecnológica é a segunda grande revolução a afetar o jornalismo de maneira significativa. A primeira teria ocorrido a partir de meados de 1950, com a criação da rotativa e dos processos de produção de jornais de massa, o que levou a uma reorientação na indústria jornalística, que teve de render lucros para se auto-sustentar. Ele adverte, entretanto, que

[...] não há 'responsáveis' por toda essa virada na forma de se fazer jornalismo. É a civilização humana como um todo que se transforma a partir de uma variável independente: a informatização. O processo digital, de tempo real, de comunicações on line estabelece novos parâmetros sociais. Tudo muda. O jornalismo, bem como os valores de progresso, evolução, e razão, foram emanações de outra época histórica, foram epifenômenos da revolução industrial e da revolução social burguesa nos séculos 18 e 19. Não seria coerente que num momento de introdução revolucionária de técnicas de inscrição, armazenamento e reaproveitamento de informações - como é a informática - sobrevivessem derivações de outras épocas históricas. (MARCONDES FILHO, 2000, p. 37)

Dessa forma, observa-se que o jornalismo passou por mudanças significativas desde o início do século XVIII. Na fase atual, não se trata de um novo suporte técnico apenas - o computador -, mas também de uma maneira diferente de produzir, difundir e receber a informação de caráter jornalístico. Esse fator se evidencia ainda mais com a difusão pela rede mundial 
de computadores (Internet), a partir da década de 90, que potencializou a interatividade, a instantaneidade e a hipermídia, quebrando, de certa forma, as fronteiras de tempo e espaço geográfico, gerando, assim, um espaço público virtual.

\section{A idéia de webjornalismo participativo parece aproximar- se das propostas de jornalismo comunitário ou de imprensa alternativa.}

Além disso, há que se considerar que a Internet rompe com o processo comunicacional vertical, de formato um-todos, até então vigente no jornalismo convencional. As novas tecnologias de comunicação, ao contrário, permitem a relação horizontal todostodos, de domínio público e caráter colaborativo, o que leva Pool a dizer que os novos media eletrônicos são tecnologias da liberdade, ou seja, aquelas que "não se pode controlar o conteúdo, que colocam em questão hierarquias, que proporcionam agregações sociais e que multiplicam o pólo de emissão não-centralizada" (POOL apud LEMOS, 2004, p. 70).

Tal liberdade favorece o aparecimento de novas formas de interação entre os indivíduos e de novas práticas sociais. A técnica é, portanto, uma invenção humana que se insere no mundo social, em suas relações políticas, econômicas e culturais, transformando o homem, a cultura e a sociedade. Nesse sentido, a atividade jornalística na rede é resultado de uma nova estrutura que se estabelece (a partir do surgimento das inovações tecnológicas) e da remodelação de configurações já existentes (o jornalismo tradicional). Eé nessa conjuntura que surgem experiências inovadoras na área, como o webjornalismo ${ }^{2}$, que teve início no Brasil em 1995, e o jornalismo participativo na Internet, prática mais recente, e que é objeto de estudo no presente trabalho.

\section{Jornalismo participativo na Internet}

A denominação "jornalismo participativo na Internet" remete à idéia de produção e publicação de notícias na rede mundial de computadores a partir de qualquer usuário. Seria, em resumo, a prática jornalística aberta a todos ${ }^{3}$.É o que alguns autores chamam de jornalismo colaborativo, comunitário, cidadão, open source $^{4}$ (código aberto), peer-to-peer ${ }^{5}$ etc. Para efeitos de padronização, optou-se por utilizar neste artigo apenas duas denominações: jornalismo participativo na Internet ou webjornalismo participativo.

A principal característica dessa nova modalidade de produção e circulação é a superação do modelo transmissionista emissor-meio-mensagem-receptor, típico do modelo convencional, uma vez que o receptor torna-se agente produtor. A idéia de participação é, justamente, descentralizar a emissão, oportunizando que mais vozes tenham vez no espaço público. Valoriza-se, dessa forma, uma forte característica da rede, que é a possibilidade de uma interatividade efetiva. Afinal, enquanto o jornal (através de cartas), o rádio (através de ligações telefônicas) e a leitura digital (através da navegação por diferentes sites), para citar alguns exemplos, permitem uma interação superficial, a prática do webjornalismo participativo constitui uma interação que vai além, possibilitando aos destinatários colaborarem com a produção dos conteúdos.

Lemos diz que "a noção de interatividade está diretamente ligada aos novos media digitais. O que compreendemos hoje por interatividade nada mais é que uma nova forma de interação técnica, de cunho eletrônico-digital, diferente da interação analógica que caracterizou os media tradicionais" (LEMOS, 2004, p. 112). Em seguida, lembra que a tecnologia digital possibilita não apenas uma interação com o objeto, mas também com o próprio conteúdo, como provam as experiências de jornalismo participativo. Nesse sentido, Primo (2000) sugere que a interatividade pode ser classificada em reativa ou mútua, sendo que a primeira depende da previsibilidade e da automação das trocas, ou seja, o usuário pode apenas escolher entre trilhas previsíveis já traçadas pelos programadores. É como navegar em um hipertexto ${ }^{6}$ de um webjornal. Já a interação mútua seria aquela em que há negociação entre os interagentes e cada ação tem impacto sobre a relação e o comportamento dos mesmos, como é o caso dos sites de jornalismo participativo.

Seguindo essa perspectiva, Primo (2003a) ainda estabelece outra classificação, baseada na abertura que os hipertextos oferecem ao usuário, a saber: 1) hipertexto potencial: aquele em que os caminhos associativos estão pré-determinados pelo programador da página. O usuário apenas escolhe o que deseja ler, sem acrescentar nada; 2) hipertexto colagem: permite uma atuação mais ativa do internauta, que já tem a possibilidade de criar, porém, ainda não se verifica um debate entre usuário e programador quanto a esta criação; 3) hipertexto cooperativo: trata-se de uma construção coletiva. Todos os envolvidos compartilham a criação de um mesmo texto, exercendo e recebendo o impacto do grupo.

Tomando-se como referência a classificação de Primo, o webjornalismo participativo pode ser definido como hipertexto cooperativo de interação mútua: não há apenas um produtor, como nas mídias de massa, mas todos os usuários podem vir a ser produtores de notícias. Esse tipo de interação ainda é pouco explorada e, por suas características, gera questionamentos quando comparadas ao jornalismo clássico. Além disso, algumas experiências de webjornalismo participativo não são totalmente abertas, o que impede a efetivação da interação mútua. 


\section{Exemplos de jornalismo participativo na Internet}

A idéia de webjornalismo participativo parece aproximar-se das propostas de jornalismo comunitário ou de imprensa alternativa, e vai ao encontro de uma necessidade do próprio público. Como observa Maffesoli, "as pessoas não querem só informação na mídia, mas também e fundamentalmente ver-se, ouvir-se participar, contar o próprio cotidiano para si mesmas e para aqueles com quem convivem. A informação serve de cimento social" (MAFFESOLI, 2004, p.23). É o que mostram algumas experiências de jornalismo participativo na Internet, que serão descritas a seguir. Pode-se observar que a criação desses sites de cooperação está, muitas vezes, vinculada a interesses políticos ou a grupos segmentados que discutem assuntos pré-estabelecidos.

\section{Não há propriamente uma ruptura entre 0 jornalismo convencional e o jornalismo participativo.}

\section{Slashdot}

Trata-se de um caso de webjornalismo participativo segmentado, que discute um assunto em específico. Fundado pelo programador americano Rob Malda, em 1997, quando tinha apenas 21 anos, o Slashdot (www.slashdot.org) foi o primeiro site construído com matérias enviadas pelos internautas e tem como tema tecnologia e informática. Hoje o empreendimento pertence à OpenSource Technology Group, e é referência mundial para notícias ligadas ao mundo digital.

Diariamente, os editores do projeto têm a tarefa de selecionar uma média de 20 notícias entre as centenas que lhes são enviadas pelos internautas. Cada uma é composta, basicamente, de um parágrafo que resume outras notícias encontradas na web e disponibiliza links para as fontes originais. Além disso, o Slashdot tem um espaço onde os internautas podem comentar cada tópico. Dessa forma, os interessados têm no site mais que uma fonte de informação, mas também um espaço de discussão especializada.

Outra característica do projeto em questão, segundo Primo e Träsel (2006), é o sistema de moderação compartilhada, no qual 400 moderadores são sorteados entre os leitores e podem votar na relevância de cada comentário (frisa-se: do comentário e não das matérias). Os valores da votação variam entre -1 e +5 e o grupo moderador tem esta tarefa por três dias, durante os quais são avaliados por "metamoderadores" escolhidos entre os mais antigos participantes do fórum, que decidem se as avaliações foram justas ou injustas. Além disso, todos os usuários também são avaliados quanto à quantidade e qualidade das parti- cipações nas discussões e quanto à qualidade de seu papel de moderador ou metamoderador. Esse sistema é conhecido como "carma", sendo que os colaboradores que tiverem classificação de "ruim" ou "terrível" não podem participar do projeto como moderadores ou metamoderadores.

\section{OhmyNews}

O site OhmyNews (www.ohmynews.com) foi criado em fevereiro de 2000 pelo jornalista sul-coreano $\mathrm{Oh}$ Yeon Ho. Conforme Brambilla (2006, p.102), o trabalho foi desenvolvido num momento em que o país sofria os reflexos da ditadura da década de 80. Com difícil acesso a informações do governo e impossibilidade de livre opinião, o povo buscou soluções para a manifestação de idéias da sociedade civil. Na redemocratização, prevaleceu o monopólio de três grandes jornais - Chosun, Jong Ang e Dong-A Ilbos - de linha editorial conservadora (assim como as tvs e rádios), ligados ao governo federal.

Com as possibilidades abertas pela Internet (início da década de 90), surgiram produtos midiáticos alternativos, como os blogs ${ }^{7}$, que passaram a apresentar um conteúdo diferenciado, mais aprofundado e distante do "jornalismo de padrão estatal" que vinha sendo veiculado na Coréia do Sul. Iniciativas assim conquistaram um público considerável, e foi baseado nesta constatação que Oh Yeon Ho lançou a idéia de que "cada cidadão é um repórter".

Inicialmente editado apenas em hangul, o alfabeto coreano, o site passou a ser publicado também em inglês a partir de agosto de 2004, sob a denominação de OhmyNews International (www.english.ohmynews.com). A partir de então, usuários de qualquer país têm a oportunidade de colaborar, de forma que a cobertura ganhou âmbito mundial. De acordo com Brambilla, hoje o jornal (inglês e coreano) conta com aproximadamente 5 mil cidadãos-repórteres ${ }^{8}$, os quais têm seu pedido de cadastramento avaliado pela coordenação do projeto. Uma vez autorizados, podem enviar imagens, vídeos, áudio ou artigos - material este que passa pela edição de jornalistas profissionais. "O trabalho de edição consiste na checagem de dados, na reescrita da manchete e na adequação do texto a uma linguagem jornalística convencional, assim como à gramática da língua inglesa" (BRAMBILLA, 2006, p. 101).

\section{Wikinews}

Baseado no sistema Wiki', o Wikinews (www. wikinews.org) é um projeto de notícias livre que permite não apenas a colaboração de todos os internautas, mas também a edição de textos já publicados, usando para isso apenas um browser ${ }^{10}$ comum. Assim, erros podem ser consertados por qualquer pessoa, notícias podem ser ampliadas ou modificadas a todo o momento, sem que haja moderadores, como no caso do OhmyNews e do Slashdot. Além disso, 
Cada notícia tem um histórico de modificações e pode ser revertida para versões anteriores, em caso de algum interagente ${ }^{11}$ acrescentar erros ou distorções, ou ainda quando há vandalismo. A maior parte do trabalho de verificação e correção é feita pelo conjunto dos colaboradores, todos na mesma posição hierárquica. Existem administradores de sistema para cada língua em que exista uma versão do Wikinews, mas seu papel é principalmente manter as ferramentas funcionando ou intervir em casos extremos de vandalismo. Se algum internauta estragar notícias de forma reincidente, pode ter seu acesso ao Wikinews bloqueado. No entanto, a política dos sistemas Wiki em geral é corrigir os problemas e esperar que os vândalos se cansem (PRIMO e TRÄSEL, 2006, p. 13).

O projeto de demonstração do Wikinews foi criado em novembro de 2004 e já em dezembro deste mesmo ano a idéia saiu da fase de demonstração e entrou na fase beta ${ }^{12}$. Neste período, a edição em língua alemã foi apresentada e apenas um mês depois foram criadas as edições em búlgaro, espanhol, francês, holandês, italiano, polonês, português, romeno, sueco e ucraniano.

\section{Estaríamos vivendo, então, uma fase de decadência do jornalista, uma vez que agora qualquer cidadão pode tornar- se um repórter?}

A versão em português, especificamente, iniciou suas atividades em 19 de fevereiro de 2005, mas os artigos de notícias só começaram a ser aceitos em 4 de março do referido ano, após ser criada a infra-estrutura necessária para o funcionamento do sistema.

\section{Exemplos no Brasil}

O grupo de comunicação O Estado de São Paulo disponibilizou on-line, a partir de 30 de outubro de 2005, a seção FotoRepórter (www.estadao.com.br/imagens/ fotoreporter), através da qual qualquer cidadão pode enviar fotografias para a publicação na rede. De acordo com Juca Varella ${ }^{13}$, sub-editor de fotografia do jornal O Estado de São Paulo e coordenador do projeto, a intenção principal é criar uma proximidade entre os leitores e os profissionais do grupo, e fornecer aos internautas materiais atualizados permanentemente, não apenas em âmbito nacional, mas também internacional. Além de serem veiculadas na Internet, com acompanhamento de legenda e crédito, as fotos enviadas pelos internautas são eventualmente utilizadas nos jornais impressos do grupo, como Jornal da Tarde e OESP, e os materiais com bom conteúdo jornalístico passam a ser distribuídos pela Agência Estado.

Já o portal Terra mantém o canal vc repórter (www.terra.com.br/vcreporter), que iniciou suas atividades em fevereiro de 2005. O objetivo é que os usuários colaborem com a produção jornalística, enviando fotos, vídeos, áudios ou depoimentos, por email ou pelo celular. Conforme consta na página de apresentação da seção, o canal de jornalismo participativo do Terra visa dar visibilidade ao cotidiano do público e à comunidade onde vive.

Outro exemplo de webjornalismo participativo no Brasil é o site Overmundo (www.overmundo.com.br). O espaço é segmentado e tem como tema a cultura brasileira, sendo que o objetivo é tornar visível toda a sua diversidade. Usuários de todo o país podem colaborar comentando, divulgando festas ou eventos, enviando textos, artigos, crônicas, músicas, filmes, fotos, dicas etc. São os próprios internautas que definem o que se publica ou o que ganha destaque no site, através de um sistema de votação.

\section{Novas práticas, novos conceitos}

A respeito das transformações que vêm sendo identificadas na prática jornalística, decorrentes, em grande parte, do estabelecimento da Internet como nova mídia, Marcondes Filho (2000, p. 37) enfatiza: "não se trata hoje de lamentar processos extintos, mas, muito ao contrário, de avaliar como revitalizar os valores decisivos que estão sendo soterrados com toda a nova agitação social". É sobre alguns desses valores do "fazer jornalístico" que nos detemos agora.

Uma vez estabelecida a possibilidade de interação mútua através do hipertexto cooperativo - ou seja, tendo-se o sujeito como agente na produção de notícias - abre-se um leque de discussões, não apenas sobre a técnica, que é relativamente nova, mas especialmente sobre as fases de produção da notícia que, como assegura Pena (2006, p. 177), são alteradas. Sobre isso, Wolton posiciona-se da seguinte forma:

Do ponto de vista de uma teoria da comunicação, isto é, da ligação entre técnica, modelo cultural e projeto social, a questão é então a seguinte: existe uma real ruptura entre as mídias de massa e a Internet? A inovação das novas tecnologias está relacionada com uma mudança cultural nos modelos individuais e coletivos? Existe, por ocasião desta nova geração técnica, um outro projeto de organização da comunicação e uma outra visão sobre o seu papel em uma sociedade aberta? Esta é a questão que é importante e não aquela da performance técnica. (WOLTON, 2003, p. 13)

A preocupação em não se deslumbrar com o chamado determinismo tecnológico ${ }^{14}$, e de considerar os vieses histórico, social e cultural, está presente não apenas no discurso de Wolton (2003), mas também 
em autores como Castells (1999), Lemos (2004) e Rüdiger (2003). Defende-se aqui que não há propriamente uma ruptura entre o jornalismo convencional e o jornalismo participativo, uma vez que existe uma linha evolutiva, em que determinadas práticas, conceitos e ideais são mantidos, e outros modificados ou acrescentados. Por outro lado, em consonância com os autores citados, considera-se necessário refletir a respeito dessa revolução eletrônico-digital (Lemos, 2004), que alterou significativamente os processos de produção jornalística nas redações tradicionais e possibilitou o aparecimento de novos produtos na área. Passemos à apreciação de alguns pontos específicos.

\section{$\mathbf{0}$ papel do jornalista e as rotinas de produçáo}

Marcondes Filho (2000) avalia que as transformações ocorridas desde 1970, com as novas tecnologias, provocaram resultados devastadores no jornalismo, pois a informática obrigou todos a entrarem num mesmo barco, onde o sistema de produção e de trânsito de informações é outro. Tudo se transformou: do papel passou-se para a tela do computador; a redação passou por uma reconfiguração física e geográfica, e, em muitos casos, foram extintas funções específicas, como pauteiros, repórteres, editores, revisores e diagramadores. A isso o autor chama de "ruptura do ambiente social" (2000). Além disso, observa que o webjornalismo quebrou a periodicidade, uma característica do jornalismo, incorporando a máxima do "tempo real". Como se essas transformações todas não bastassem, graças ao advento da Internet, já não é mais o jornalista o único responsável pela produção de notícias. Muda, portanto, o papel desse profissional, assim como as rotinas de produção, que se alteram em decorrência da tecnologia.

Estaríamos vivendo, então, uma fase de decadência do jornalista, uma vez que agora qualquer cidadão pode tornar-se um repórter? Exemplos como o OhmyNews justificam-se pela insatisfação em relação à mídia tradicional; já o Slashdot e o Overmundo refletem a busca por um conteúdo segmentado; canais como vc repórter (Terra) e FotoRepórter (Estadão), parecem ser mantidos pela vontade do público de "se ver na mídia", e também pela vontade das empresas de ampliar o raio de cobertura. Assim, o jornalista depara-se com "cidadãos comuns" exercendo o seu papel, o seu ofício, o que, por sua vez, pode ser aniquilado ou transformado: de repórter passa-se a mero avaliador ou selecionador de matérias prontas, de conteúdos.

Não há mais a rotina da reunião de pauta, saídas externas para contatar as fontes, entrevistá-las e fotografá-las. Não há mais a redação textual conforme os padrões do jornalismo tradicional (lead, pirâmide invertida, legenda etc.), nem o trabalho de revisão e diagramação. Afinal, o que rege esta nova prática? $\mathrm{O}$ que garante que o conteúdo enviado pelos internautas esteja realmente completo e seja verídico? Guardadas as reconhecidas vantagens da Internet como meio de comunicação - agilidade, tempo real, atualização constante, multimidialidade etc. - há que se questionar até que ponto o webjornalismo participativo tem credibilidade e qualidade, duas questões fundamentais do jornalismo convencional e que parecem esmaecer frente à nova prática.

Por mais que haja jornalistas atuando como moderadores (o que ocorre em alguns casos, como no Ohmynews, vc repórter e FotoRepórter), o trabalho é limitado à revisão e edição do material que lhes é enviado, deixando de lado as tarefas corriqueiras que envolvem a cultura profissional e enriquecem a produção jornalística. Além disso, pode-se questionar: onde fica a relevância de critérios como interesse público, veracidade, objetividade, clareza, exatidão, linguagem adequada? Tem-se uma situação em que todos esses pressupostos parecem diluir-se de tal forma que o jornalismo torna-se, pelo menos numa análise preliminar, simplista, superficial, pouco sério. As tecnologias digitais de comunicação e informação vão, assim, ao encontro daquilo que Marcondes Filho (2000) chama de "teoria neoliberal da transparência", em que cada um fala e divulga o que julga relevante - seja por interesse político, pessoal, econômico, etc.

\section{De Gatekeeper a Gatewatcher}

Pena (2006) nos lembra que na sociedade pós-industrial o bem mais valioso é a informação. E aí, segundo o autor, entra em cena uma função fundamental dos jornalistas: a de mediador, que dá nome ao conceito de gatekeeper (definição originalmente utilizada por David White). Estudos sobre este tema concluíram que as decisões dos selecionadores de notícias sempre estão mais influenciadas por critérios profissionais, ligados às rotinas de produção (como os fatores de noticiabilidade ${ }^{15}$, falta de espaço, repetição, falta de qualidade do material, interesses publicitários, etc.) do que por uma avaliação individual e subjetiva. Já no caso do webjornalismo participativo, no entanto, isso muda de figura: não há mais o fator espacial (pois a Internet é "ilimitada") e os cidadãos-repórteres não têm a devida cautela jornalística ou comercial para com o material que publicam.

Uma vez que os "cidadãos-comuns" são transformados em agentes produtivos, conclui-se que eles sejam também portões selecionadores (gatekeepers): de tudo que vivenciam, assistem e tomam conhecimento, escolhem o que mais lhes interessa para publicar no veículo on-line. O que resta, então, aos jornalistas? Conforme Bruns (2003), estes passam a filtrar o conteúdo disponível na rede ou enviado por colaboradores, e são então chamados de gatewatchers. Esse trabalho se faz necessário, segundo o autor, porque, como na rede não há um limite de espaço, há necessidade se de avaliar as informações, e não de descartá-las. Para o autor em referência, o valor do gatewatching está em filtrar a informação e republicá-la em um contexto específico, dependendo dos interesses do público de um site determinado.

Vantagens de um lado, dúvidas de outro. Conside- 
ra-se positivo o fato de oportunizar aos internautas a colaboração com a produção jornalística, no papel de gatekeepers, pois podem cobrir um vácuo deixado pela mídia tradicional de massa. Em contrapartida, questiona-se até que ponto qualquer pessoa pode interferir nesse processo. Como o "jornalista-vigia" sustentará a credibilidade do seu trabalho se tem nas mãos conteúdos encaminhados por desconhecidos, a maioria leigos no campo jornalístico? Eis aí uma tecla bastante batida pelos defensores do jornalismo tradicional e que parece estar sendo esquecida pelos profissionais - talvez pela comodidade do trabalho colaborativo (poupa tempo, dinheiro e traz agilidade), talvez pela concorrência ("ora, se os outros fazem, por que ficarei para trás?"), ou até mesmo pela idéia fixa de democratização, que sempre foi um dos objetivos do jornalismo e, conforme acreditam alguns autores, vem sendo sustentada mais do que nunca com a Internet.

\section{Considerações finais}

Seria pretensioso propor respostas conclusivas para as reflexões que se iniciam neste artigo. A intenção deste trabalho não é definir se o jornalismo participativo na Internet é bom ou ruim, certo ou errado. Far-seá, no entanto, algumas considerações para aguçar a crítica e, assim, fomentar o debate a respeito.

Acredita-se que as tecnologias digitais de comunicação e informação tenham trazido contribuições importantes ao trabalho jornalístico, especialmente no que diz respeito aos processos de produção e edição. Porém, as mudanças ocorrem em um ritmo intenso, de forma que, de equipamento de apoio, tais tecnologias transformaram-se em novos suportes midiáticos, graças ao estabelecimento da Internet. Isso tudo provoca o surgimento de novos produtos (entre os quais está o webjornalismo participativo), o que cria a necessidade de repensar práticas, conceitos e teorias que até então vinham norteando as reflexões sobre o trabalho jornalístico.

A nova modalidade tem contribuído para que jornalista venha assumindo um papel mais passivo e acomodado no processo, perdendo algumas das características que sempre compuseram o seu perfil profissional, como a preocupação constante com a ética, a verdade, a busca da objetividade, a participação nos processos de elaboração e apuração da notícia, como reuniões de pauta (onde se dá o trabalho do gatekeeper), saída a campo, investigação, contato com as fontes, cruzamento de informações, redação das matérias, produção de fotos, revisão e diagramação.

Ora, com a prática do jornalismo participativo na Internet, o trabalho dos jornalistas - quando há resume-se ao gatwatching, ou seja, à vigilância dos materiais enviados pelos internautas (na sua maioria, desconhecidos), nos quais é depositada a confiança de que estão relatando a verdade acima de tudo (um dos princípios legitimadores do jornalismo).

A partir do momento em que qualquer elemento do público tem o poder de selecionar aquilo que será veiculado, passa a ser de sua responsabilidade uma das atribuições que tradicionalmente as sociedades modernas atribuem aos jornalistas: a de produzir representações da realidade. Em termos de história do jornalismo, portanto, parece regressar-se no tempo. No século XV, o jornalismo era meramente opinativo, produzido por vozes poderosas, como os políticos; depois, passou a ter os jornalistas como mediadores; agora, com o webjornalismo participativo, parece estar-se vivenciando um retorno ao jornalismo opinativo, uma vez que qualquer pessoa com acesso à Internet tem a possibilidade de exercer o papel de jornalista, articulista, analista dos fatos do dia. Com isso, também podem ser difundidas inverdades ou matérias comprometidas por interesses políticos, pessoais, econômicos etc.

Admite-se que uma das vantagens da nova prática jornalística seja a possibilidade de cobrir acontecimentos que a mídia de massa deixa em segundo plano. Além disso, o jornalismo participativo na Internet surge como uma boa estratégia para que as empresas cortem custos com a contratação de repórteres. Afinal, se há milhares de internautas colaborando gratuitamente, para que contratar mais jornalistas? Porém, por trás de todas essas vantagens, recoloca-se a pergunta: que jornalismo é esse? Que estratégias o regem exatamente? Onde fica o compromisso social, a ética e a credibilidade? Superficialmente, o que parece importar é o mero fluxo de informações, sendo que questões mais profundas são esquecidas.

Poder-se-ia ainda confrontar a idéia de jornalismo participativo na Internet com outras perspectivas teóricas, como a teoria do espelho, a gnóstica, a instrumentalista ou a etnográfica, citadas por Pena (2006), e que também podem ser revisadas diante das novas práticas. A proposta deste artigo, no entanto, foi apenas a de iniciar um debate em torno dessa temática que chega trazendo inquietações. mfamecos

\section{NOTAS}

1. De acordo com Primo e Träsel (2006), considera-se que o webjornalismo participativo remete às práticas desenvolvidas em seções ou na totalidade de um siteem que a participação do público é essencial para a produção do texto informativo. Os $b \operatorname{logs}$ jornalísticos também se incluem nessa classificação, apesar de não serem discutidos neste artigo.

2. Mielniczuk (2003) define webjornalismo como publicações jornalísticas veiculadas na World Wide Web (WWW), e o classifica em primeira, segunda e terceira geração. A primeira geração corresponde à mera transposição dos jornais para a Internet; a segunda, quando, mesmo atrelado ao impresso, começam a ser explorados recursos oferecidos pela 
rede, como links; e a terceira geração se configura a partir do momento em que as potencialidades da rede - multimidialidade, instantaneidade e interatividade - começam a ser efetivamente utilizadas para fins jornalísticos. Observa-se, a partir dessa classificação, que o jornalismo participativo na Internet decorre justamente de uma característica potencial da rede, que é a possibilidade de intervenção dos usuários, os quais abandonam a condição de leitores e passam a ser também produtores de notícias.

3. Informações mais detalhadas sobre esta prática podem ser encontradas em Brambilla (2006).

4. Conforme Moura (2002), o termo open source surge aplicado ao software que algumas pessoas criam e disponibilizam gratuitamente na rede para que qualquer usuário possa manipulá-lo, e vem sendo adaptado a outras áreas, como no caso do jornalismo, o que gerou a expressão jornalismo open source. Trata-se, portanto, da combinação da prática jornalística com a abertura do código-fonte de softwares, ou seja, as ferramentas de publicação.

5. Segundo Moura (2002), a expressão jornalismo peerto-peer sugere um jornalismo que envolve a partilha de recursos e serviços através da troca entre sistemas.

6. De acordo com Lévy (1993, p. 33), "tecnicamente, um hipertexto é um conjunto de nós ligados por conexões. Os nós podem ser palavras, páginas, imagens, gráficos ou partes de gráficos, seqüências sonoras, documentos complexos que podem eles mesmos ser hipertextos. Os itens de informação não são ligados linearmente, como em uma corda com nós, mas cada um deles, ou a maioria, estende suas conexões em estrela, de modo reticular. Navegar em um hipertexto significa, portanto, desenhar um percurso em uma rede que pode ser tão complicada quanto possível. Porque cada nó pode, por sua vez, conter uma rede inteira".

7. Trata-se de um tipo de página pessoal em que o proprietário publica conteúdo sobre um ou vários assuntos e deixa aberto um mural onde os visitantes podem expor suas opiniões.

8. Nome dado aos usuários que participam da produção de notícias on-line em sitescolaborativos.

9. Sistema que permite a colaboração na produção de conteúdo na web, utilizando um browser comum e sem a necessidade de saber programar com a linguagem HTML.

10. Programa utilizado para navegar na Internet (In- ternet Explorer ou Netscape, por exemplo). Habilita seus usuários a interagirem com documentos HTML hospedados em um servidor Web.

11. Segundo Primo (2002), a denominação "usuário" torna-se insuficiente quando o sujeito passa a ter autonomia para interferir na esfera digital. Ele não apenas usa, mas age frente à informação. Por isso a denominação "interagente".

12. Versão beta é a inicial. Em geral só circula na própria empresa onde foi desenvolvida. Provavelmente tem muitas imperfeições, que são posteriormente corrigidas.

13. Ver entrevista completa em: http:// observatorio.ultimosegundo.ig.com.br/ artigos.asp? $\operatorname{cod}=354 \mathrm{ASP} 005$

14. Segundo Rüdiger (2003), o determinismo tecnológico se refere à faculdade emancipatória e beneficente da técnica moderna. A tecnologia é vista como fator progressivo da humanidade (otimismo exagerado).

15. No livro Técnicas de codificação em jornalismo (2001), Mário Erbolato classifica critérios de noticiabilidade como aqueles que motivam o público, entre os quais elenca: proximidade, impacto, raridade, progresso, interesse pessoal, importância etc.

\section{REFERÊNCIAS}

BARROS FILHO, Clóvis de. Ética na comunicação: da informação ao receptor. Colaborador: Pedro Lozano Bartolozzi. São Paulo: Moderna, 1995.

BRAMBILLA, Ana Maria. Jornalismo open source: discussão e experimentação do OhmyNews International. Porto Alegre: UFRGS, 2006. Dissertação (Mestrado em Comunicação e Informação), Faculdade de Biblioteconomia e Comunicação, UFRGS, 2006.

BRUNS, Axel. “Gatewatching, not gatekeeping: collaborative online news". Media International Australia, n. 107, pp. 31-44, 2003. Disponível em: http:/ / eprints.qut.edu.au/archive/00000189/.

CASTELLS, Manuel. A Sociedade em Rede. A Era da Informação: economia, sociedade e cultura. v.1. São Paulo: Paz e Terra, 1999a.

CAVALCANTI, Mario Lima. A aposta do Estadão no jornalismo participativo. Disponível em: http:/ /observatorio.ultimosegundo.ig.com.br/ 
artigos.asp? cod=354ASP005. Acesso em: 2 ago. 2006.

HOHLFELDT, A.; MARTINO, L. C.; FRANÇA, V. V. Teorias da comunicação: conceitos, escolase tendências. Petrópolis (RJ): Vozes, 2001.

LEMOS, André. Cibercultura: tecnologia e vida social na cultura contemporânea. 2 ed. Porto Alegre: Sulina, 2004. 295 p.

LÉVY, Pierre. As Tecnologias da Inteligência. Editora. 34. São Paulo 1993. 230p.

MAFFESOLI, Michel. A comunicação sem fim (teoria pós-moderna da comunicação). In: MARTINS, Francisco Menezes; SILVA, Juremir Machado da. (orgs). A genealogia do Virtual: Comunicação, Cultura e Tecnologias do Imaginário. Porto Alegre: Sulina, 2004. 278 p.

MARCONDES FILHO, Ciro. Comunicaçãoe jornalismo: a saga dos cães perdidos. São Paulo: Hacker Editores, 2000.

MEDINA, Cremilda de Araújo. Notícia: um produto à venda: jornalismo na sociedade urbana e industrial. São Paulo: Alfa-Omega, 1978. 194 p.

MELO, José Marques de. A opinião no jornalismo brasileiro. 2 ed. Petrópolis: Vozes, 1994. 208 p.

MIELNICZUK, Luciana. Jornalismo na Web: uma contribuição para o estudo do formato da notícia na escrita hipertextual. Salvador: UFBA, 2003. Tese (Doutorado em Comunicação), Programa de Pós-Graduação em Comunicação e Cultura Contemporânea, Universidade Federal da Bahia, 2003.

MOURA, Catarina. O jornalismo na era Slashdot. 2002. Disponível em: http:// www.bocc.ubi.pt/pag/moura-catarinajornalismo-slashdot.pdf. Acesso em 24 jul. 2006.

PENA, Felipe. Teoria do jornalismo. 2 ed. São Paulo: Contexto, 2006.

PRIMO, Alex. Interação mútua e interação reativa: uma proposta de estudo. Revista da Famecos, n. 12, p. 81-92, jun. 2000.

PRIMO, Alex Fernando Teixeira; RECUERO, Raquel da Cunha. Hipertexto Cooperativo: Uma Análise da Escrita Coletiva a partir dos Blogs e da Wikipédia. Revista da FAMECOS, n.22, p. 54-65. Dez. 2003a.

PRIMO, Alex. Quão interativo é o hipertexto? Da interface potencial à escrita coletiva. Revista Fronteiras: estudos midiáticos, v. V, n. 2, p. 125-142, Dez. 2003b. Disponível em: http:/ / www6.ufrgs.br/limc/PDFs/ quao_interativo_hipertexto.pdf.

PRIMO, Alex; TRÄSEL, Marcelo. Webjornalismo participativo e a produção aberta de notícias. In: UNIRevista, vol. 1, no 3, julho/2006.

Disponível em: www.unirevista.unisinos.br. Acesso em 10 ago. 2006.

REVISTA ÉPOCA. Edição 430. Agosto/2006. Você faz a notícia: como funcionam os sites Digg.com e OhMyNews - onde o cidadão comum é o jornalista - e qual é o real poder deles. Renata Leal.

RÜDIGER, Francisco. Introdução às teorias da cibercultura: perspectivas do pensamento tecnológico contemporâneo. Porto Alegre: Sulina, 2003. 151 p.

SEÇÃO FOTO REPÓRTER. Disponível em: www.estadao.com.br/imagens/fotoreporter. Acesso em: 2 ago. 2006.

SEÇÃO “VC REPÓRTER”. Disponível em: www.terra.com.br/vcreporter. Acesso em: 2 ago. 2006.

TRAQUINA, Nelson. Teorias do Jornalismo: Porque as notícias são como são. v. 1. Florianópolis: Insular, 2004.

WOLF, Mauro. Teorias da comunicação. Tradução de Maria Jorge Vilar de Figueiredo. 4 ed. Lisboa: Presença, 1995. 247 p.

WOLTON, Dominique. Internet, e depois?: uma teoria crítica das novas mídias. Tradução: Isabel Crosseti. Porto Alegre: Sulina, 2003. 232 p. 